\title{
Glacier retreat and melt-lake expansion at Stephenson Glacier, Heard Island World Heritage Area Kevin Kiernan and Anne McConnell
}

School of Geography and Environmental Studies, University

of Tasmania, Hobart, Tasmania 7005, Australia

Received September 2001

ABSTRACT. Historical records, recent observations, and geomorphological evidence indicate that rates of retreat and downwasting of the tidewater Stephenson Glacier, and concurrent expansion of ice-marginal melt-lakes, has increased by an order of magnitude since 1987. Melt-lake expansion is partly the product of greatly accelerated ablation of older, ice-cored twentieth-century moraines. The timing of these changes broadly coincides with reported increases in atmospheric and sea-surface temperatures around other sub-Antarctic islands, but correlates less well with changes along the northern Antarctic Peninsula, where warming has been more rapid. These recent changes in landscape character and geomorphological processes have implications for geodiversity, biodiversity, and cultural heritage values in this World Heritage Area. If the causal climatic warming is anthropogenic, it reinforces the fact that even the most remote and littlevisited nature conservation reserves may be compromised by off-site human impacts, confronting management authorities with difficult philosophical and practical issues.

\section{Contents}

Introduction

Physical environment

297

Methods

Results

Interpretation of results

Discussion

Conclusions

Acknowledgements

References

307

307

\section{Introduction}

Widespread glacier retreat in the sub-Antarctic since 1950, and retreat and ice-shelf decay in the Antarctic Peninsula since the early $1980 \mathrm{~s}$, has occurred coincident with significant warming of atmospheric and sea-surface temperatures (Smith and Steencamp 1990; Doake and Vaughan 1991; Gordon and Timmis 1992; Vaughan and Doake 1996; Cosimo 2000; Alley and Bindschadler 2001). This paper records and interprets glacier retreat and landscape changes at Stephenson Glacier on Heard Island $\left(72^{\circ} 32^{\prime} \mathrm{E}\right.$, $53^{\circ} 06$ 'S), a sub-Antarctic wilderness reserve and World Heritage Area in the southern Indian Ocean (Fig. 1). Heard Island occurs in a region from which there have been few detailed studies of recent glacier retreat or of the terrestrial record and impact of climate change. Such climate change may have important implications for geomorphological processes in some conservation reserves, and for management of their natural and cultural values (Bridgewater 1996; Stone 1996; Galloway and others 1998). If glacier recession on Heard Island is due to anthropogenic climate change (Green 2000), it provides further evidence of the potential for even the most remote of nature conservation preserves to be compromised by human impacts.

\section{Physical environment}

Heard Island is dominated by Big Ben, a strato-volcano 20 $\mathrm{km}$ in diameter that rises $2745 \mathrm{~m}$ into the stormy subAntarctic atmosphere and exerts a major influence on the local climate. A smaller volcanic complex, Laurens Peninsula, extends westwards from Big Ben, and Elephant Spit extends $\sim 10 \mathrm{~km}$ downdrift from the eastern side of the mountain. The mean annual temperature (MAT) recorded between 1948 and 1954 when a permanent base was maintained at Atlas Cove, between Laurens Peninsula and Big Ben, was $1.3^{\circ} \mathrm{C}$, with a seasonal variation in temperature at sea level of $\sim 4^{\circ} \mathrm{C}$. The maximum recorded temperatures are $15.8^{\circ} \mathrm{C}$ at Atlas Cove and $21^{\circ} \mathrm{C}$ at Spit Camp on the north coast at the inner end of Elephant Spit, and the lowest recorded temperature is $-9^{\circ} \mathrm{C}$. Recorded annual average precipitation at Atlas Cove is $1350 \mathrm{~mm}$. Snow falls to sea level throughout the year (Allison 1980; Australian Antarctic Division 1995). Steep and rapidly flowing glaciers descend to tidewater from Big Ben. Their equilibrium line altitude (ELA) lies close to sea level, and they are sensitive indicators of climate change (Ruddell and Allison 1997). Laurens Peninsula has also been glaciated to sea level in historical time, but its glaciers are now confined above $400 \mathrm{~m}$ altitude.

Stephenson Glacier descends $\sim 11 \mathrm{~km}$ down the eastern flank of Big Ben between the glacially abraded Graham Ridge and the youthful volcanic construct of Scarlett Hill, then broadens to form a piedmont lobe up to $\sim 3 \mathrm{~km}$ wide (Fig. 2). East of its present terminus lies the large Dovers Moraine complex, which stretches north-south across the apex of Elephant Spit and now deflects the glacier into lobes that flow northeast and southeast. A smaller lateral moraine complex has formed west of Stephenson Lagoon below Scarlett Hill, while in the south an interlobate drift complex $\sim 1 \mathrm{~km}$ wide has formed between Stephenson Glacier and an ice stream that formerly descended southwest of Graham Ridge (Fig. 1).

Little ground-based geomorphological data have previously been available to aid in studies of glacier recession and geomorphic change on Heard lsland. Historical and photographic records suggest that there was no significant change in the extent of the glaciers between 1874 and 


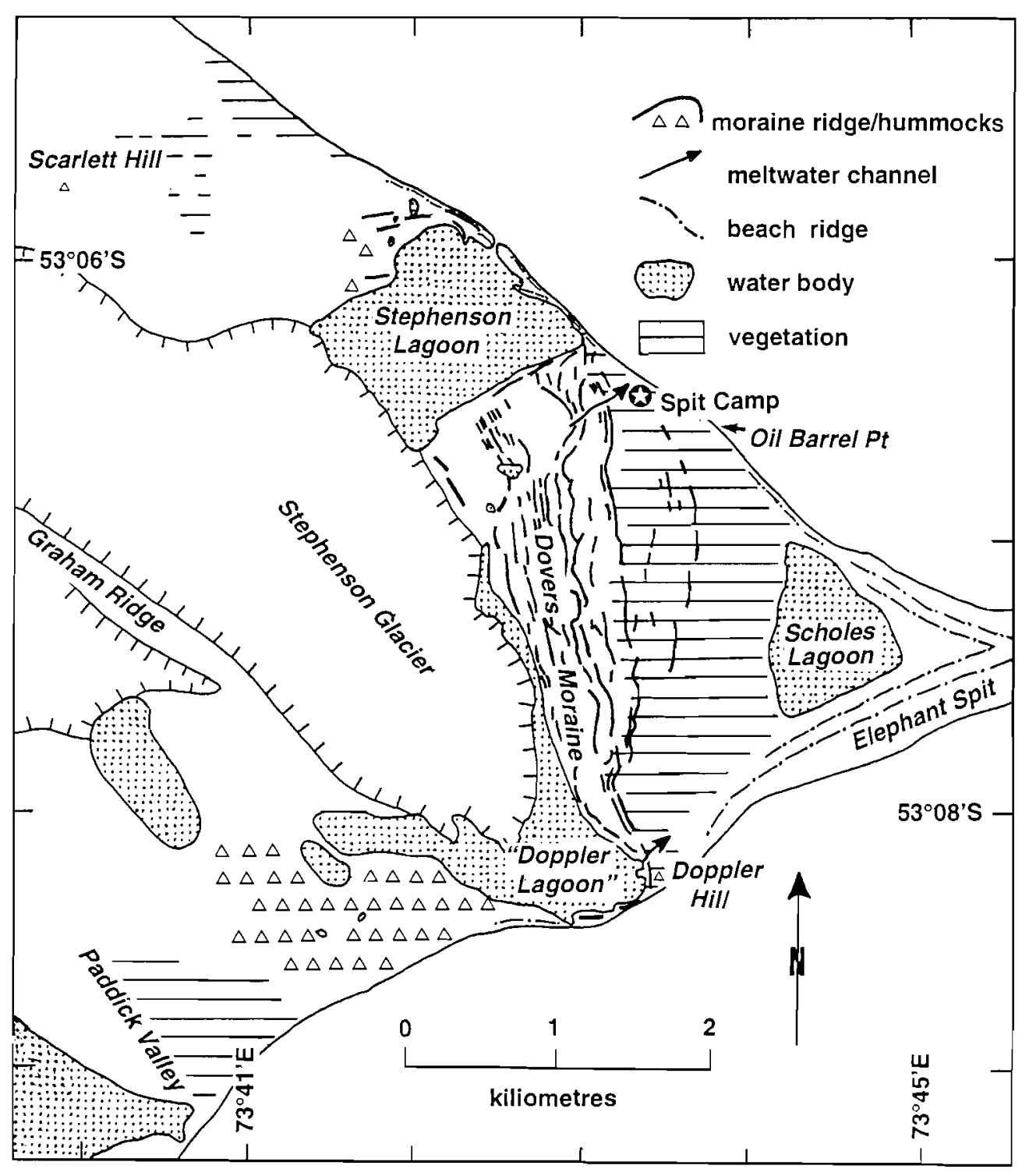

Fig. 1. Principal landforms as at November 2000 , and localities mentioned in the text.

1929 , but that there was minor recession by 1955 and major recession of most glaciers had occurred by 1963 (Budd 1964a, 1964b, 2000; Budd and Stephenson 1970). Some asynchronous retreat and advance of different glaciers took place during the following decade (Budd 1973, 2000), after which continuing recession occurred (Allison and Keage 1986; Garvin and others 1999; Kiernan and McConnell 1999; Green 2000).

\section{Methods}

Changes in glacier margins and the extent of melt-lakes prior to 1997 have been determined from historical and recent photographs, published reports and maps, unpublished data obtained by Australian National Antarctic Research Expeditions (ANARE), communication with early ANARE expeditioners, SPOT images, and geomorphological observations made in March 1997 and November 2000. Delineation of ice limits and melt-lake extent in March 1997 is based on observations from the air, oblique aerial photographs, and partial ground-level inspection. Approximations of the glacier and lake margins as at
November 2000 were derived from oblique aerial photography and ground-level inspection of the entire Dovers Moraine complex, GPS control points, and reference to new vertical aerial photographs of part of the area (Fig. 3).

Moraines and outwash channels were mapped from aerial photographs and ground survey. Generalised topographic profiles over Dovers Moraine were compiled using a clinometer, staff, and fibreglass tape. Comparisons of soil development across different parts of the Dovers Moraine complex were used as an aid to determining the likely relative age of moraine ridges. The altitudes of melt-lake palaeo-shorelines were measured to determine the minimum altitude of the glacier margin that impounded the lakes.

\section{Results}

\section{Review and interpretation of historical records} $1850 s-1960$

An historical sketch produced during the sealing days on Heard Island (1850s-70s) depicted high ice cliffs on the southern coast between Doppler Hill and Paddick Valley 


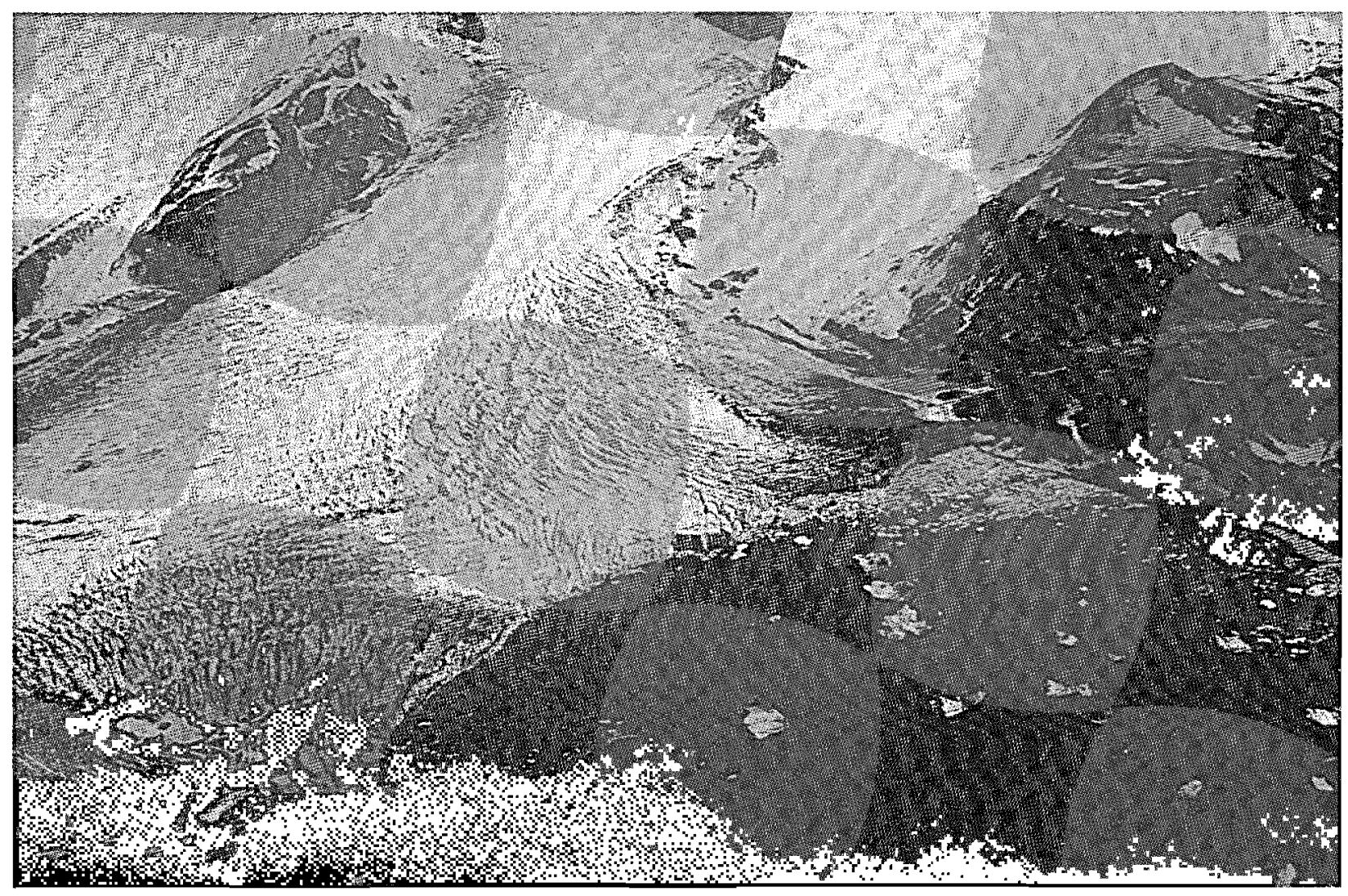

Fig. 2. Oblique aerial photograph of the northern margin of Stephenson Glacier. Graham Ridge is on the left and Scarlet Hill on the right.

(Downes 1996: 87, fig. 14). Oblique aerial photographs taken in 1947 recorded heavily ridged, debris-mantled ice reaching the south coast, and a major meltwater stream discharging eastwards between Doppler Hill and the main part of Dovers Moraine (ANARE ref 515-635, 639). In 1949 Ealey, Chittleborough, and Paddick encountered overhanging ice cliffs on the south coast, inland of a narrow beach (ANARE log 1949, AAD Library Heard Island collection, microfiche sheet 59; Paddick 1993). A hydrographic chart produced in 1949 similarly depicted ice to the coast (Hydrographic Branch 1949), as did a 1951 ANARE map bound with Downes and others (1959). On the basis of these records the 1947 ice edge depicted in Figure 3 follows Budd and Stephenson (1970), who indicated the Stephenson Glacier as having reached the coast at that time. However, an alternative interpretation has been presented by Allison and Keage (1986) who depicted the glacier proper as having terminated several hundred metres inland, and who apparently regarded the ice-cored moraine closer to the coast as being older.

In 1947 the northern margin of the glacier reached the coast, where steep ice cliffs were being undercut by the sea. The 1947 photographs suggest that the glacier reached high up the western slopes of Dovers Moraine. Interpretation is complicated by the distant view and difficulty in differentiating snow from ice, but the present-day trough between the glacier and Dovers Moraine was certainly icefilled.
In 1954 ice-cored moraine still formed cliffs 3-4 m high along the south coast between Doppler Hill and Paddick Valley, inland of a beach that was too narrow to be traversed safely by ground parties (G. Budd, personal communication, 26 April 2001). Coastal ice cliffs $15 \mathrm{~m}$ high persisted on the northern margin of the glacier. The Stephenson Glacier still reached close to the crest of Dovers Moraine in at least some areas.

\section{0-1980}

By 1963 the Stephenson Glacier had retreated $\sim 1 \mathrm{~km}$ from the south coast and Graham Ridge had emerged more prominently through the downwasting ice. The northern ice margin lay $100 \mathrm{~m}$ inland behind a beach and lagoon (Budd and Stephenson 1970) and the ice surface lay $20 \mathrm{~m}$ below the northeastern crest of Dovers Moraine. Observations in 1965, 1969, and 1971 indicated generally continuing retreat, although some re-advance occurred between 1963 and 1971 (Budd 1970; Budd and Stephenson 1970; Allison and Keage 1986). In 1971 a lake several hundred metres wide was present between the ice edge and northeastern Dovers Moraine, from which a large stream flowed down a meltwater channel to the coast beside the presentday ANARE Spit Camp (Budd 2000; G. Budd, personal communication, 26 April 2001).

In 1980 the southern glacier margin still lay within $\sim 1$ $\mathrm{km}$ of the coast although the precise boundary between icecored moraine and active debris-mantled ice is uncertain. A terminal lake had started to form $\sim 1.5 \mathrm{~km}$ from the coast 


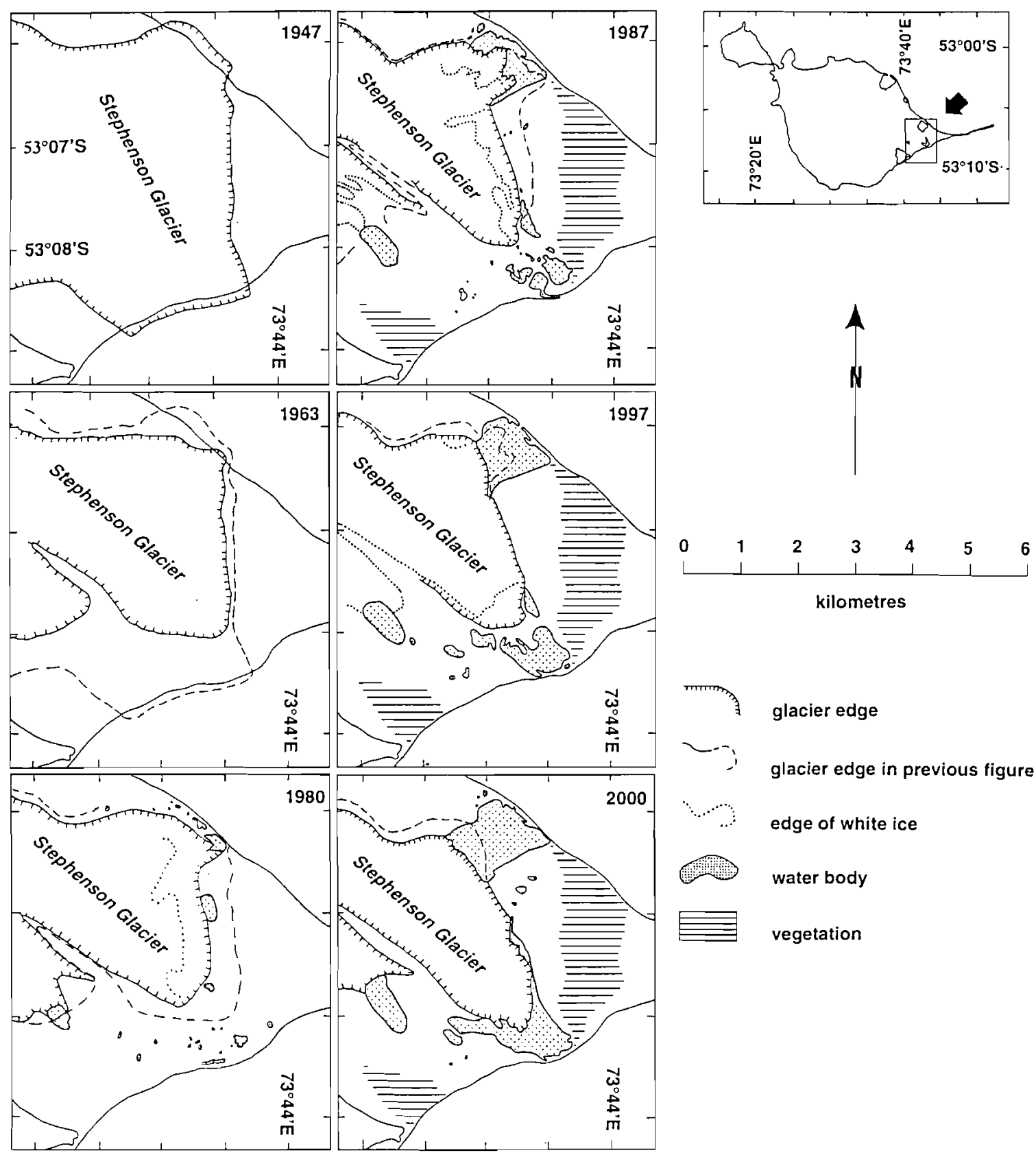

Fig. 3. Glacier and melt-lake extents in 1947, 1963, 1980, 1987, 1997, and 2000. The 1947 and 1963 limits are after Budd and Stephenson (1970) and the 1980 limits are after Allison and Keage (1986).

(altitude $\sim 180-200 \mathrm{~m}$ ) on the smaller ice stream southwest of Graham Ridge (Allison and Keage 1986). The northern glacier edge had retreated another few hundred metres and a proglacial lake of 6 ha (the proto Stephenson Lagoon) extended $\sim 260 \mathrm{~m}$ inland. A lake of $\sim 100$ ha was still present between Stephenson Glacier and Dovers Moraine. 1980-early 1990s

The proglacial lake below Graham Ridge grew from $\sim 11$ ha in 1980 to $\sim 23$ ha by 1987 , by which time numerous smaller ponds had also formed in the ice-cored moraine between Stephenson Glacier and Paddick Valley. By 1987 a cluster of smaller lakes and ponds had also appeared towards the coast west of Doppler Hill. Melt lakes totalling $\sim 6$ ha had existed in this latter area in 1980 , but some had expanded and coalesced to form a lake of $\sim 27$ ha by 1988. The largest single lake, here informally termed 'Doppler Lagoon,' extended over $\sim 13$ ha immediately southwest of Doppler Hill, and another lake of $\sim 8$ ha had formed close to the position of the December 2000 lagoon outlet. The area of smaller lakes farther west had expanded from $\sim 0.07$ ha in 1980 to $\sim 1.8$ ha in 1987 .

By 1988 the northern margin of the glacier still closely abutted rock bluffs on the southeastern flanks of Scarlet Hill, whereas the terminal ice cliffs now lay $\sim 500$ m inland. The glacier surface had become less strongly convex and one narrow tongue of the $\sim 115$ ha Stephenson Lagoon extended for nearly $1 \mathrm{~km}$ inland between the glacier and Dovers Moraine. There was only a small remnant pool 


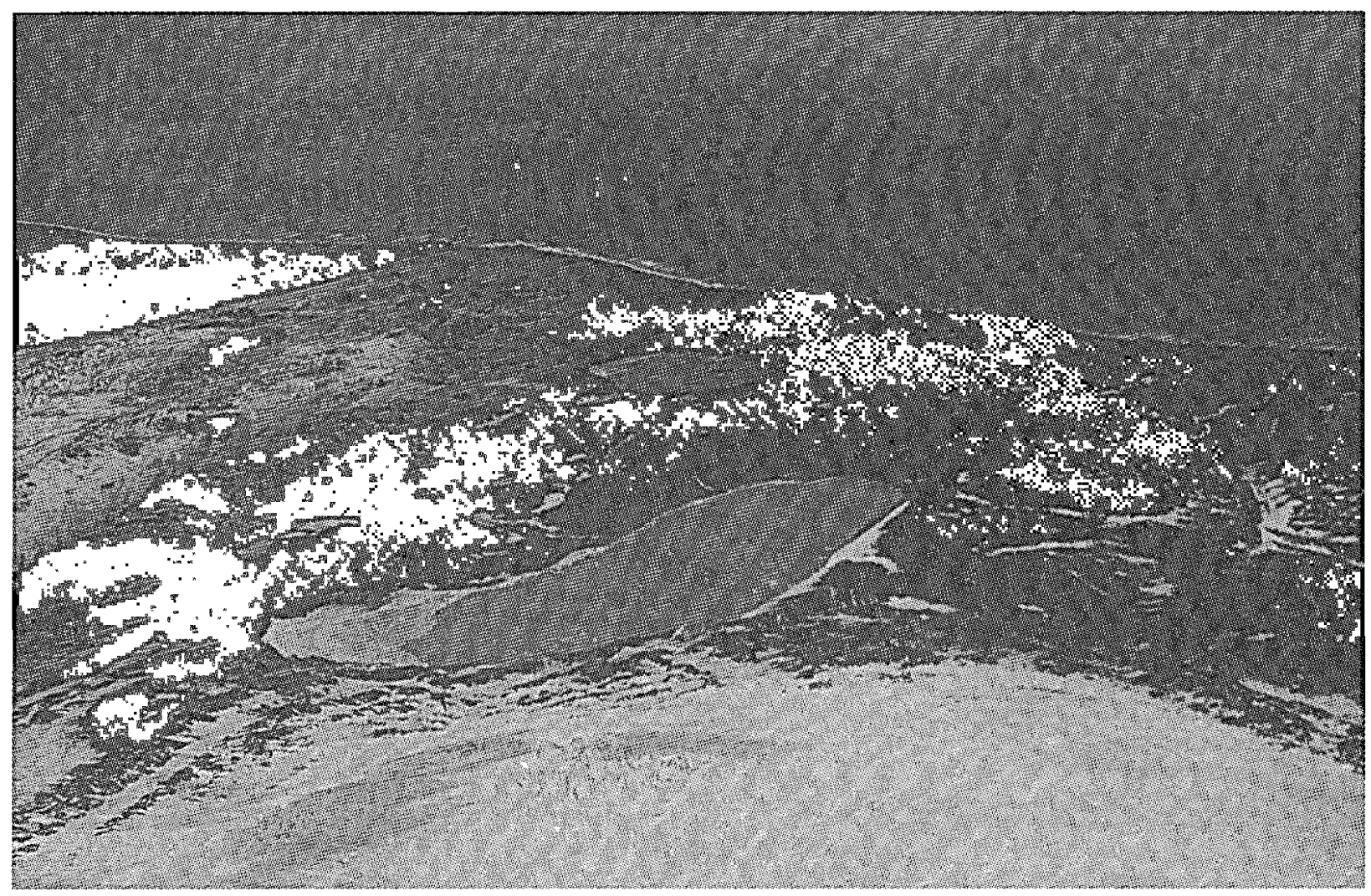

Fig. 4. Oblique aerial photograph of the southwestern margin of Doppler Lagoon taken from above Graham Ridge, December 2000. The lake at the terminus of the small ice stream southwest of Stephenson Glacier is in the foreground.

$\sim 150 \mathrm{~m}$ in diameter where the 100 ha lake had been impounded between the ice edge and Dovers Moraine in 1980 , but a new lake $\sim 750 \mathrm{~m}$ long and $200 \mathrm{~m}$ wide (area $\sim 130$ ha) had formed farther south, reaching to within $\sim 300$ $m$ of the other lakes expanding inland from the south coast. Green (1992) recorded that between 1987/88 and 1992/93 Doppler Lagoon enlarged appreciably, and an extensive lake remained present on the eastern ice margin.

\section{New observations in 1997 and 2000}

Glacier margins and melt-lake extent

By March 1997 Doppler Lagoon had grown to more than 58 ha and reached $>1 \mathrm{~km}$ inland. The separate lake southwest of Graham Ridge was $\sim 1 \mathrm{~km}$ long (area $29 \mathrm{ha}$ ). Some lakes in the ice-cored drift towards Paddick Valley had enlarged significantly, but a few appear to have drained. The outlet from Doppler Lagoon was closed in March 1997 and there was no evidence of the significant discharge eastwards between Doppler Hill and Dovers Moraine recorded by the 1948 photographs. The small lake formerly present at the outlet to this latter meltwater channel had contracted.

The northern glacier margin formed ice cliffs $15-20 \mathrm{~m}$ high $\sim 1 \mathrm{~km}$ from the coast, the ice front having receded almost the full depth of the 1987 inlet between the glacier and Dovers Moraine. The northern edge of the glacier had receded laterally from Scarlet Hill, and rock was exposed extensively along the northern arm of an amphitheatre $\sim 1.5 \mathrm{~km}$ north of Graham Ridge. Stephenson Lagoon had grown to $\sim 180$ ha and was strewn with icebergs, with waves breaking weakly through a breach in the coastal barrier. Remnants of the terminal moraine were present on the westernmost part of the coastal barrier, but few were discernible at the eastern extremity. The lake between the ice margin and Dovers Moraine had grown to $\sim 80$ ha but only a few small pools persisted within depressions higher on Dovers Moraine. Localised instability due to ice-core melting was still evident at $\sim 45 \mathrm{~m}$ altitude near the head of the Spit Camp meltwater channel.

By November 2000 the lake southwest of Graham Ridge had grown to well over $1 \mathrm{~km}$ length and broadened appreciably at its upstream end (area $\sim 38 \mathrm{ha}$ ). An arm of Doppler Lagoon, formed by coalescence of numerous smaller melt lakes, extended nearly $2 \mathrm{~km}$ along the southwestern edge of Stephenson Glacier (Fig. 4). Doppler Lagoon had also coalesced with the large lake between the glacier and Dovers Moraine to form a continuous water body that extended to within $714 \mathrm{~m}$ of Stephenson Lagoon (Fig. 5). The outlet from Doppler Lagoon to the sea remained closed in mid November but a few weeks later it temporarily broke out, lowering the level of the extensive lagoon by nearly $1 \mathrm{~m}$ in less than 24 hours. By November 2000 the terminal moraines on the south coast had been erased from all but the easternmost extremity of the Doppler Lagoon barrier.

By November 2000 the western part of Stephenson Lagoon had broadened by $400 \mathrm{~m}$ and its area had enlarged to $\sim 270$ ha (Fig. 6). The northwestern edge of the glacier 


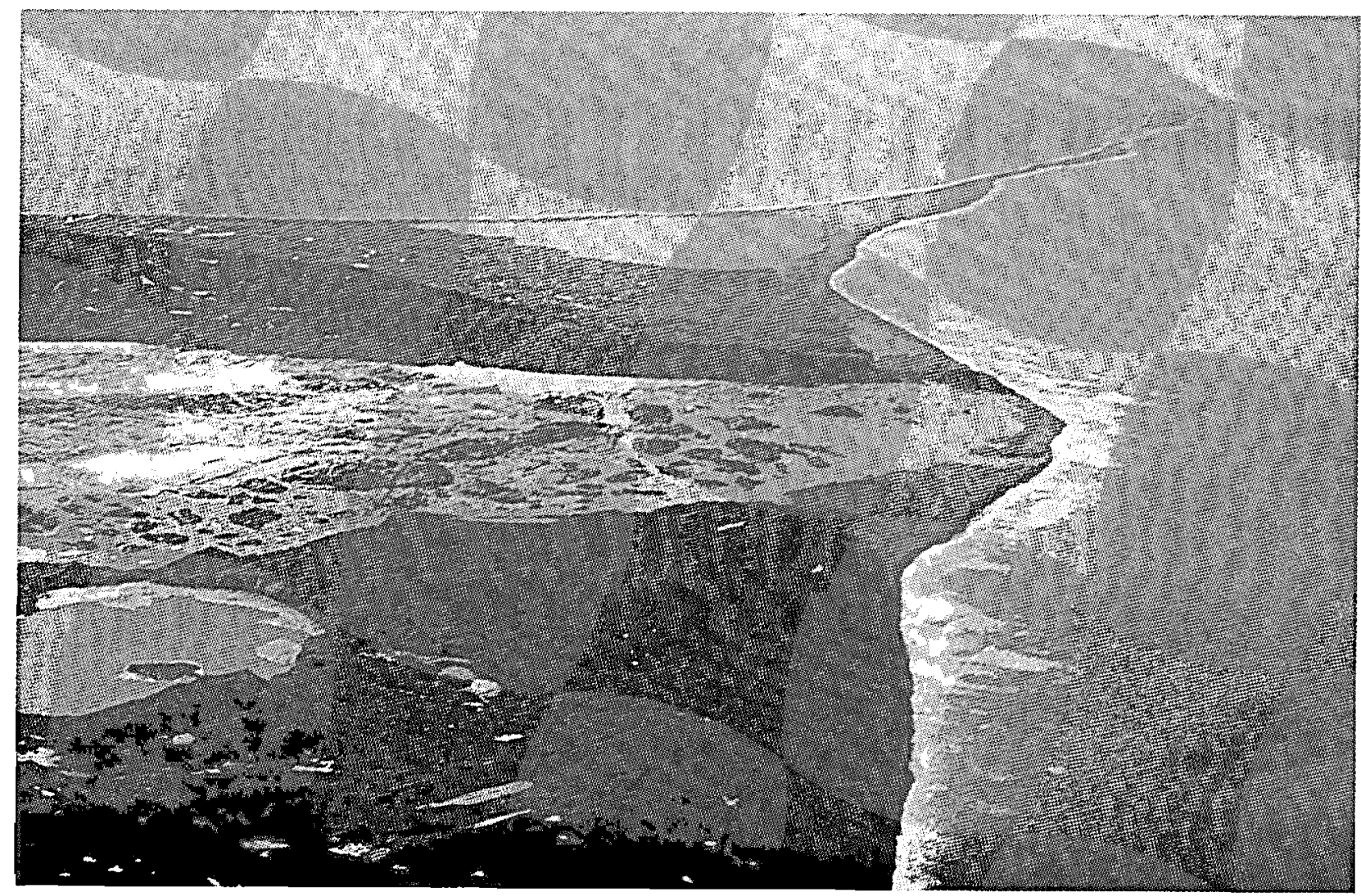

Fig. 5. Oblique aerial photograph of the southern coast, taken from above Paddick Valley. The largest water body is Doppler Lagoon. The Dovers Moraine complex and a sequence of glaciofluvial fans occur between Doppler Lagoon and Scholes Lagoon. Elephant Spit is visible in the background.

had retreated appreciably, rock bluffs had emerged more prominently through the downwasting glacier on the lower slopes of Big Ben, and supraglacial debris was slightly more abundant on the western margin of the ice. The surface profile of the glacier was more concave than in 1997 and the ice margin at the lagoon edge less steep, although ice cliffs up to $\sim 15 \mathrm{~m}$ high were still present, principally towards the southeastern corner of Stephenson Lagoon, where the glacier rides up onto the foot of Dovers Moraine.

The few high level pools in Dovers Moraine that contained water in early November 2000 had contracted markedly or dried out entirely a few weeks later, leaving minor silty strandlines that were quickly degraded during occasional rainstorms. Active ice-core disintegration was still evident near the head of the Spit Camp meltwater channel, and at up to $60 \mathrm{~m}$ altitude farther south along Dovers Moraine. The eastern margin of the glacier had downwasted to near sea level, leaving a broad trough between the ice edge and Dovers Moraine.

\section{Geomorphological evidence}

The contrast between stable, well-vegetated moraine slopes and glaciofluvial fans on the ice-distal side of the Dovers Moraine complex and the unstable and unvegetated condition of the still ice-cored proximal slopes suggests significant age differences. Similarities in slope stability, vegetation cover, and soil development suggest that the more vegetated moraines here are of broadly comparable age to those at Paddick Valley. Some stream channels that drain the ice margin in the Paddick Valley area, which Allison and Keage (1986) found had persisted between 1947 and 1980, remained in 2000 substantially as depicted on the 1985 map. This suggests that in more heavily vegetated parts of the moraine complexes, ice-core disintegration is relatively complete.

Topographic profiles constructed across the Dovers Moraine complex reveal the relative positions, height, and form of the principal moraine ridges (Fig. 7). Soil investigations at three sites on the unvegetated ice-proximal side of the main crest of Dovers Moraine (W1, W2, and W3) revealed an increase in pedogenic alteration of the tills with distance from the ice margin. The least weathered of these profiles comprised uniform and homogeneous stony and silty sand-gravel till, which occurs on the crest of a small moraine within $50 \mathrm{~m}$ of Stephenson Glacier (site W1, altitude $\sim 7 \mathrm{~m}$ ). This till is loose at the surface but slightly compacted below $12 \mathrm{~cm}$. Profile colour varies from pale grey-brown (10YR2/1) at the surface to greybrown $(7.5 Y R 2-1.7 / 1,7.5 Y R 1.7 / 1)$ at depth. Field pH grades from 7.5 at the surface to 8 below $12 \mathrm{~cm}$ depth.

Sediment that forms the two sampled moraines more distant from the ice edge proved significantly more weathered. At the crest of Dovers Moraine (site W3, altitude 80 $\mathrm{m}$ ) the ground surface is $90 \%$ armoured by deflated sub- 


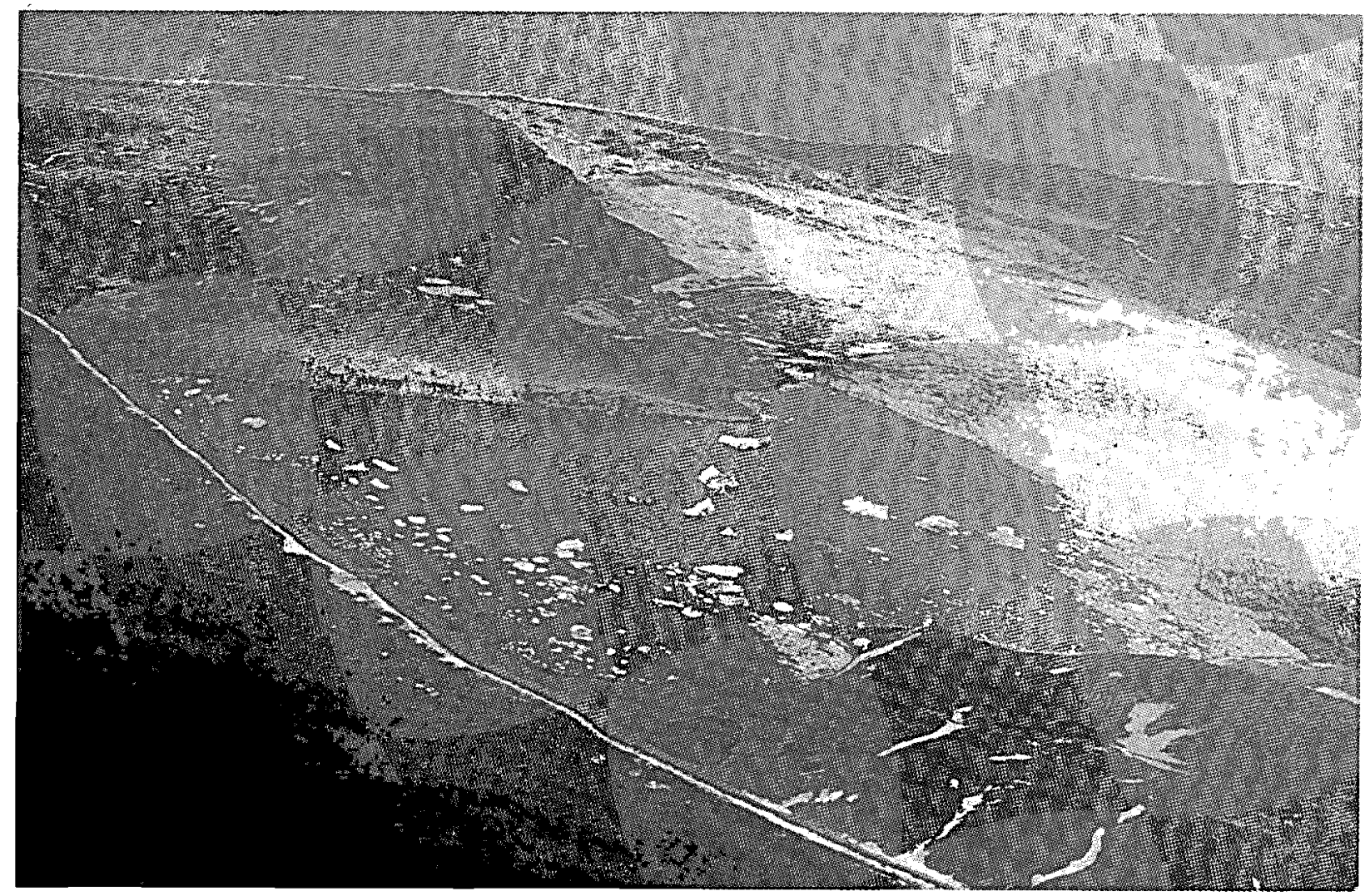

Fig. 6. Oblique aerial photograph southeastwards across Stephenson Lagoon and the Stephenson Glacier terminus, December 2000. The ridge to the left of the lagoons and glacier is Dovers Moraine.

angular to sub-rounded clasts of coarse gravel to boulder grade. Vegetation cover is $\sim 5 \%$. The till comprises a sequence of finer and coarser sediments that exhibit a systematic colour change from grey-brown (5YR2/1-2) at the weathered surface to browny-grey (5-7.5YR2/1) at depth. Clasts below $35 \mathrm{~cm}$ are fresher and more angular than those near the surface. Fine silt coatings occur around many stones but there is no evidence of fine sediment cappings. An unvegetated moraine crest closer to the ice margin (site W2, altitude $70 \mathrm{~m}$ ) is comparably weathered. Here $60-70 \%$ of the surface is armoured by sub-angular to sub-rounded gravel to cobbles that overlie firm, uniform, and homogeneous stony, slightly clayey, silty sand-gravelly till. The sediment colour ranges from $7.5 \mathrm{YR} 3 / 1$ at the weathered surface to $7.5 \mathrm{YR} 2 / 2$ to $7.5 \mathrm{YR} 2 / 1$ at depth. Field $\mathrm{pH}$ ranges from 8 at the surface to 9 at depth. At $\sim 23$ $\mathrm{cm}$ depth the sediment becomes more compact without any change in composition. Incipient solifluction terraces are present on the northern flanks of this moraine.

These observations suggest that some pedeogenic change has occurred at sites W2 and W3, and that the unmodified till profile at site $\mathrm{W} 1$ is much younger. The very lightly vegetated moraine crest at $\mathrm{W} 3$ and the unvegetated moraine crest at W2 may be of broadly comparable age but both appear significantly older than the recent (1980s?) moraine at W1. Incipient periglacial terraces on the northern slopes of the W2 moraine also suggest that it is significantly older than slopes closer to the present ice margin, from which terraces are absent.
The Spit Camp meltwater channel intake is at $\sim 48 \mathrm{~m}$ altitude amid the unvegetated moraines. Remains of a camp established during the sealing period (1853-75) occur $3-4 \mathrm{~m}$ from the channel thalweg at the coast. The location of this camp is likely to have been at least partly influenced by the availability of a water supply. That there has been no significant gravel deposition subsequently at the sealers' site suggests that a proglacial lake formed a sediment sink at the head of the channel. Narrow, closely spaced benches of predominantly medium-fine gravel and coarse sand, often extending laterally for tens of metres, are conspicuous at several locations on the ice-proximal slopes of a broad re-entrant between moraine ridges along the western face of the Dovers Moraine complex. These benches are interpreted as palaeo-shorelines of former icedammed water bodies. Topographic profiles were constructed across two flights of these shorelines (Fig. 8). The first profile originated at the northeastern margin of a small residual pond $27.5 \mathrm{~m}$ above Stephenson Lagoon at the northern end of the re-entrant. This profile intersected two high shorelines at $59.8 \mathrm{~m}$ and $58.8 \mathrm{~m}$ altitude, at $675 \mathrm{~m}$ and $655 \mathrm{~m}$, respectively, from the November 2000 ice edge, and 11 lower palaeo-shorelines $(44.6,43.0,40.8,40.2$, $39.4,38.8,38.2,37.5,36.0,34.6$, and $32.0 \mathrm{~m}$ ) between 560 $\mathrm{m}$ and $460 \mathrm{~m}$ from the ice edge. The second profile extended from the November 2000 ice edge farther to the south (GPS 0413338/4114176) into the mouth of the same re-entrant. This intersected four palaeo-shorelines (27.4, $25.8,23.8$, and $21.4 \mathrm{~m}$ altitude) between $300 \mathrm{~m}$ and $345 \mathrm{~m}$ 


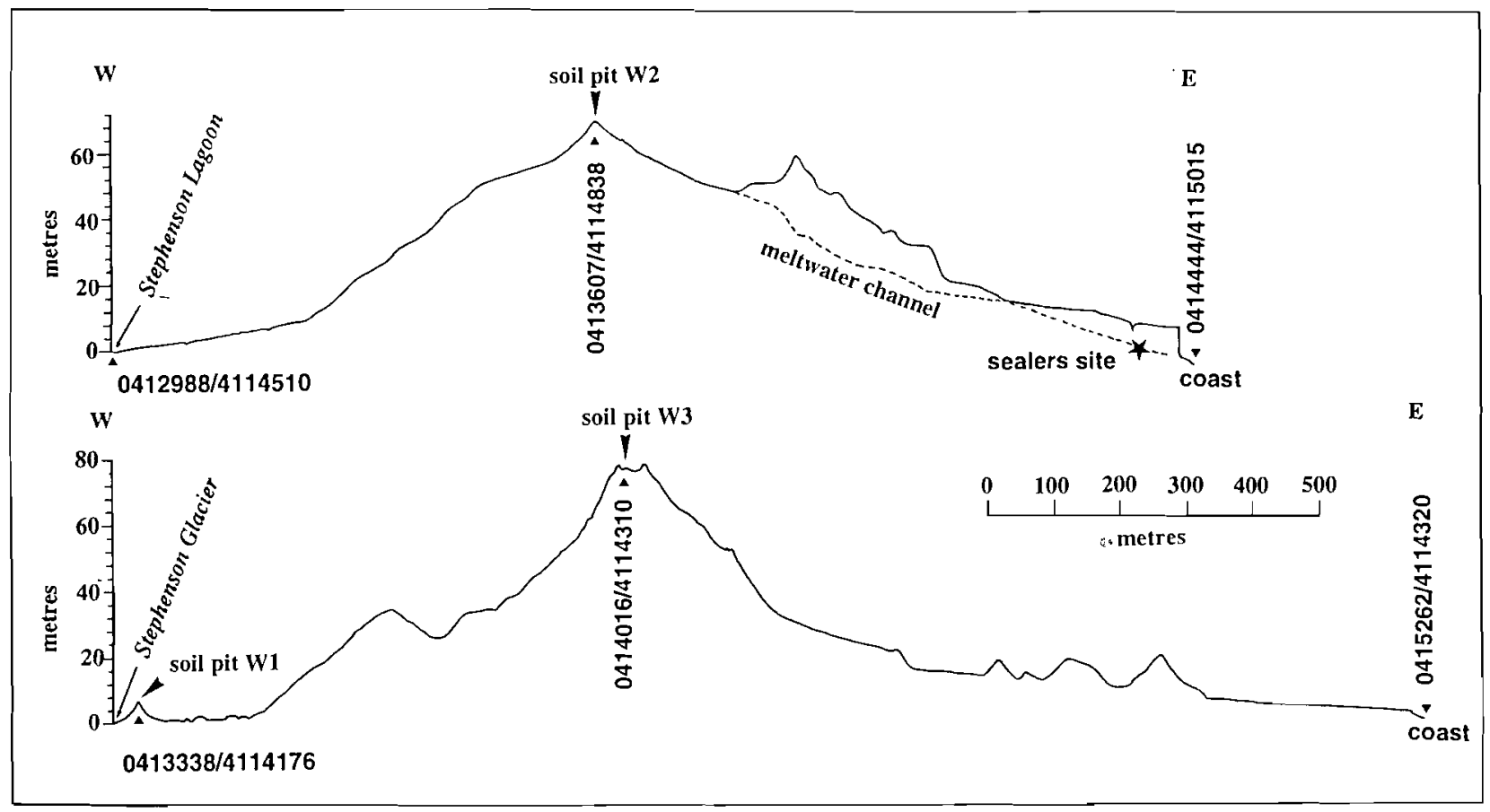

Fig. 7. Topographic profiles over Dovers Moraine.

from the ice edge, and a further six palaeo-shorelines $(19.8,13.8,10.4,9.2,8.8$, and $7.8 \mathrm{~m})$ between $234 \mathrm{~m}$ and $268 \mathrm{~m}$ from the ice edge.

\section{Interpretation of results}

Recession has been most marked on the northern margin of Stephenson Glacier, which retreated at a mean rate of $\sim 18$ $\mathrm{m} \mathrm{a}^{-1}$ from 1947 to 1987 before retreat accelerated dramatically to $\sim 100 \mathrm{~m} \mathrm{a}^{-1}$ between 1987 and 2000 . The southern margin of Stephenson Glacier appears to have retreated less consistently than the northern margin. The boundary between debris-mantled glacier and older ice-cored moraine is locally ambiguous and the apparently slightly greater ice extent in the south in 1987 compared to 1980 and 1963 may be an artefact of inadequate base maps. Irrespective of these relatively minor uncertainties, the overall trend is a general diminution of ice volumes in the terminal zone of Stephenson Glacier. The mean position of the white ice on the southern glacier margin appears to have retreated $\sim 960 \mathrm{~m}$ between 1947 and 1963, but only $\sim 200 \mathrm{~m}$ between 1963 and 1987 with little subsequent retreat. Not all margins of the glacier may remain grounded, evidence for possible minor readvance of the southern edge between 1997 and 2000, despite retreat elsewhere, hinting that the ice may locally be afloat in Doppler Lagoon, and hence be susceptible to minor marginal fluctuations.

Retreat of the eastern margin of Stephenson Glacier has been less spectacular than that of the southern and northern margins due to the confining effect of Dovers Moraine. The $60 \mathrm{~m}$ palaeo-shoreline on the ice-proximal side of the W2 moraine implies that the glacier was not in contact with at least part of that moraine when the lake existed. The palaeo-shorelines at $\sim 44.6 \mathrm{~m}$ altitude imply that the glacier margin in the early 1970 s, when water was observed discharging from a lake into the Spit Bay meltwater channel, lay $\sim 370 \mathrm{~m}$ to the southwest of the channel intake. The re-entrant that contains the palaeo-shorelines below $48 \mathrm{~m}$ altitude is the probable site of the large lake present in 1980, implying that the ice edge then lay no more than $300 \mathrm{~m}$ east of the glacier edge position as of November 2000 . The second flight of shorelines farther to the south records progressive retreat of the ice margin $300 \mathrm{~m}$ westwards during the 1980s and 1990s.

Overall melt-lake formation around the margins of Stephenson Glacier increased from a mean rate of $\sim 2.9$ ha $\mathrm{a}^{-1}$ between 1947 and 1987 to $\sim 11.3$ ha $\mathrm{a}^{-1}$ between 1987 and 2000. Rates of melt-lake expansion are not directly proportional to glacier retreat rates because some of the lake expansion has resulted from wasting of older twentieth-century ice-cored moraines in the Doppler Lagoon area, and the formation of localised deep re-entrants between the glacier and adjacent moraines. On the northern margin of the glacier where ice-cored moraines are less abundant, Stephenson Lagoon expanded at a mean rate of $\sim 0.35 \mathrm{ha} \mathrm{a}^{-1}$ from 1963 to 1980 , accelerating to $\sim 6.9$ ha $\mathrm{a}^{-1}$ from 1980 to 1987 . The mean expansion rate from 1987

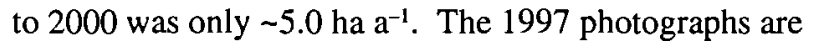
uncontrolled, but available evidence suggests expansion of Stephenson Lagoon may have slowed to $\sim 3.5 \mathrm{ha} \mathrm{a}^{-1}$ between 1987 and 1997, but then accelerated dramatically to $\sim 10 \mathrm{ha} \mathrm{a}^{-1}$ between 1997 and 2000. Doppler Lagoon expanded at a mean rate of $\sim 0.3$ ha $\mathrm{a}^{-1}$ between 1947 and 1980 but this increased to -3.2 ha $\mathrm{a}^{-1}$ between 1980 and 1987. It remained at $\sim 3.1$ ha $\mathrm{a}^{-1}$ between 1987 and 1997 but then accelerated dramatically to $\sim 11.9$ ha a $^{-1}$ between 1997 and 2000. Even allowing for some probable imprecision in these values the overall trend is clear. 


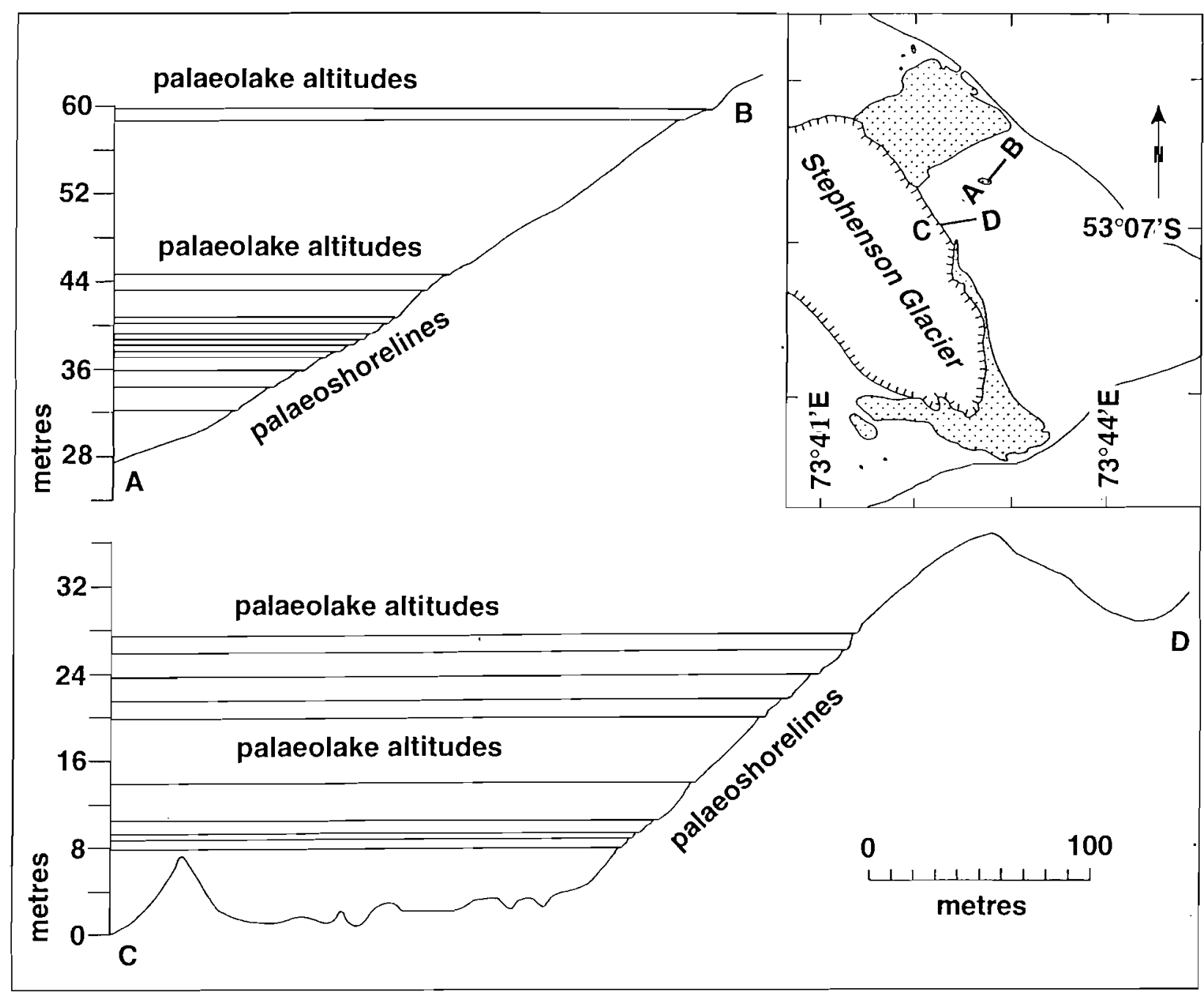

Fig. 8. Topographic profiles over lake palaeo-shorelines.

Minimal sedimentation along the old Spit Camp meltwater channel over the last century may be attributable to the intervention of an ice-contact lake that acted as a sediment sink. For a lake to have existed in this position requires that the $\mathrm{W} 2$ and $\mathrm{W} 3$ moraines were already in place. The uppermost lake palaeo-shorelines would allow spillage into this meltwater channel, but those below $48 \mathrm{~m}$ altitude would not and hence must post-date 1971 , when a vigorous flow was recorded. If the $60 \mathrm{~m}$ palaeo-shoreline were assumed to date from 1947, it would imply lowering of the ice surface on the eastern margin of the glacier at a mean rate of $\sim 0.4 \mathrm{~m} \mathrm{a}^{-1}$ between 1947 and the cessation of discharge down the Spit Camp meltwater channel some time after 1971. The palaeo-shorelines in the W2 flight record thinning of the glacier by $\sim 18 \mathrm{~m}$ between the early 1970s and draining of the large lake on the eastern ice margin in the early 1980s. The second set of palaeoshorelines farther to the south indicates that the ice-surface altitude declined $\sim 20 \mathrm{~m}$ during the 1980s and 1990s. Together, these palaeo-shorelines imply lowering of the ice margin at a mean rate of $\sim 1.1 \mathrm{~m} \mathrm{a}^{-1}$ since the early 1970s.

Only a broad estimate of ice-volume loss is possible in the absence of data on subglacial topography. In December 2000, a down-glacier ice-surface gradient of $\sim 40 \mathrm{~m}$ $\mathrm{km}^{-1}$ was estimated over the final $1 \mathrm{~km}$ of Stephenson Glacier, normal to the eastern margin near the re-entrant. This gradient is probably not representative of gradients applicable before the 1980 s, historical photographs suggesting that gradients were relatively low to the east, where flow was constrained by Dovers Moraine, but that gradients were steeper to the north and south. However, in combination with the ice-margin altitudes determined from the lake palaeo-shorelines, the figure of $40 \mathrm{~m} \mathrm{~km}^{-1}$ provides some basis for approximating past ice-surface altitude farther up-glacier. Extrapolation from these data suggest an ice-surface altitude $\sim 1 \mathrm{~km}$ from the present (2000) ice edge of $\sim 100 \mathrm{~m}$ in the late $1940 \mathrm{~s}, \sim 88 \mathrm{~m}$ in the early $1970 \mathrm{~s}$, $\sim 70 \mathrm{~m}$ in the early $1980 \mathrm{~s}, \sim 60 \mathrm{~m}$ in the late $1980 \mathrm{~s}, \sim 50 \mathrm{~m}$ in 1997 , and $\sim 45 \mathrm{~m}$ in 2000 . Coupled with the estimated ice extent at these times, these figures suggest that the cross-sectional area of ice above sea level at the foot of Big Ben has diminished $\sim 30 \%$ in the last 30 years.

\section{Discussion}

While volcanic activity may cause local changes to ice 
masses, and basal melting may be enhanced by an elevated geothermal heat flux, the similar patterns of glacier retreat on both Heard and nearby Kerguelen islands confirm that retreat has been driven by climatic factors (Allison and Keage-1986). Recession of these glaciers over the last half-century has been attributed to a rise in atmospheric air temperatures and a steady rise in sea-surface temperature (Radok and Watts 1975; Allison and Keage 1986; Budd 2000).

Glaciers that originate low on Big Ben have shown the most marked recession during historical time because they have a low mass flux and a high proportion of their total area at low altitude, and are therefore sensitive to a balance shift (Ruddell and Allison 1997). However, the major icevolume loss described in this paper involves one of the largest and most favourably positioned glaciers on Heard Island. Originating high on the slopes of Big Ben, Stephenson Glacier also occurs on the leeward eastern slopes of the mountain, which rises across the path of the prevailing westerly airstream. Glacial erosion is pronounced on these flanks consistent with accumulation of windblown snow on the leeward side of the mountain. The velocity of Stephenson Glacier is not known but fluctuations of the budget in the narrow accumulation zone of the Vahsel Glacier on the southwestern slopes of Big Ben are transmitted to the terminus in $\sim 100$ years (Allison 1980; Allison and Keage 1986). By analogy, the dramatic diminution of the Stephenson Glacier in the 1960s and 1970s, and its accentuation over the last two decades, probably indicates recent climatic changes.

Mean annual temperature for 1948-54 at Atlas Cove was $1.3^{\circ} \mathrm{C}$. Records from an automatic weather station (AWS) installed at Atlas Cove in 1981-82 indicate a mean temperature of $2.7^{\circ} \mathrm{C}$. Ruddell and Allison (1997) used glacier-climate modelling to infer a $0.8^{\circ} \mathrm{C}$ warming at Heard Island since the 1940s. AWS data for the period 1 April 1997-1 December 2000 indicate that between the authors' 1997 and 2000 inspections of Dovers Moraine and Stephenson Glacier mean temperatures for Atlas Cove and Spit Bay were 2.1 and $2.4^{\circ} \mathrm{C}$, respectively. Hence, mean temperature at Heard Island was $\sim 0.9^{\circ} \mathrm{C}$ warmer for the $1997-2000$ period than for $1948-54$ but $\sim 0.6^{\circ} \mathrm{C}$ cooler than for 1981-82.

Sea-surface temperatures (SST) around Heard Island were relatively stable from 1880 until the 1920s (Green 2000 ) or 1940s (Paltridge and Woodruff 1981), but they have increased steadily, accompanied by widespread glacier retreat and accelerated marine and aeolian erosion of coastal landforms, since the early $1950 \mathrm{~s}$. SST rose by $\sim 1{ }^{\circ} \mathrm{C}$ from the 1930 s to 1980 . Green (2000) recorded SSTs at Spit Bay in winter 1992 that were $\sim 0.5-2.0^{\circ} \mathrm{C}$ warmer than figures recorded for the same months at Atlas Cove in 1950 , although the two sampling sites were not entirely comparable. Mean annual SST at $52.5^{\circ} \mathrm{S}$ was $0.3^{\circ} \mathrm{C}$ warmer for both 1981-82 and 1997-2000 than for 194754.

Green (2000) raised the possibility that following breaching of the coastal barrier at Stephenson Lagoon in 1992, and occasional breaching of the barrier at Doppler Lagoon, warmer marine waters and tidal influences might accelerate glacier retreat. However, expansion of Stephenson Lagoon did not accelerate following breaching of the bar and both lagoons remain dominated by discharge from the hinterland rather than by tides. Retreat of Stephenson Glacier has been accompanied by equally dramatic downwasting and a reduction of ice-surface gradients in the terminal zone, suggesting that lake and lagoon thermo-erosion and mechanical effects have played only a secondary role relative to increases in atmospheric temperature. The greater relative significance for icemass decay of increased atmospheric temperature is also suggested by the more pronounced break-up of ice shelves around the Antarctic Peninsula in those locations where melt ponds have expanded due to lengthening of the melt season as climate has warmed. Regions that show melting without pond formation remain relatively unchanged despite the increase in SST (Scambos and others 2000).

Glacier retreat on both Heard Island and nearby Kerguelen conforms broadly to a similar atmospheric warming trend (Frenot and others 1993; Garvin and others 1999; Budd 2000). MAT at Heard Island increased $1.8^{\circ} \mathrm{C}$ between 1948 and 1951 and remained $1.3^{\circ} \mathrm{C}$ higher in the middle 1950s. A similar pattern has been demonstrated from Kerguelen where a decrease of $0.8^{\circ} \mathrm{C}$ in the early 1960 s was followed by rewarming of $1.3^{\circ} \mathrm{C}$ by 1982 and persistence of these warmer temperatures. The Kerguelen record for $1981-82$ shows an MAT $0.5^{\circ} \mathrm{C}$ warmer than either the 1951-54 period or the mean for 1951-96. Based on model studies using temperatures from four stations surrounding Heard Island, Jacka and Ruddell (1998) concluded the record from Kerguelen provided the best available proxy for Heard Island MATs.

A major shift in cyclone paths between 1950 and 1980 was recognised by Budd and Stephenson (1970), Radok and Watts (1975), and Allison and Keage (1986). Simmonds and Keay (2000) have recently shown that between 1958 and 1997 annual and mean southern hemisphere extratropical cyclone densities were reduced at most locations south of $40^{\circ} \mathrm{S}$. The annual average number of southern hemisphere cyclones rose from 1958 to a maximum of $\sim 39$ in 1972 but then declined, with counts in the 1990s being particularly low. A similar pattern was evident when counts were confined to the $50-70^{\circ}$ band. Simmonds and Keay (2000) argued that the depth of systems is perhaps the most useful measure of their climatological influence. Cyclone diameters and depth both show a positive trend over the 40 -year period, diameters increasing by $5 \%$ between 1971 and the late 1980 s and 1990s. The greatest increases in depth occurred south of Australia and in the eastern Indian Ocean, which are the regions of greatest mean system density.

Trends in sub-Antarctic glacier response to changing atmospheric and oceanic circulation similar to those observed on Heard Island have been demonstrated from 
South Georgia since 1950 (Gordon and Timmis 1992) and from Marion Island where air temperature increased by $1.6^{\circ} \mathrm{C}$ between 1968 and 1985 and of SST by $1.2^{\circ} \mathrm{C}$ during the same period (Smith and Steencamp 1990). A southward shift in the edge of summer sea ice by $2.8^{\circ}$ of latitude occurred between the mid-1950s and early 1970s (de la Mare 1997). A warming trend is also evident along the Antarctic Peninsula, but correlation with sub-Antarctic sites is poor. Several ice shelves in the northern Antarctic Peninsula have retreated or disappeared in the last few decades, and there has been a distinct change in calving styles and increasing retreat since the early 1980s, accelerating into the 1990s (Vaughan and Doake 1996; Doake and Vaughan 1991; Scambos and others 2000). Ice-shelf extent appears to be correlated with station air temperatures (King 1994), which indicate strong regional warming. Weather records from several stations on the Antarctic Peninsula indicate warming by $-2.5^{\circ} \mathrm{C}$ since the late 1940 s, coincident with a $20 \%$ reduction in sea-ice extent in the Bellinghausen and Amundsen seas (Jacobs and Comiso 1997). This rate of warming is much more rapid than that evident from Heard Island or other sub-Antarctic or Antarctic sites.

\section{Conclusions}

Rates of both glacier retreat and melt-lake enlargement have increased by about one order of magnitude during the last two decades. Precise ice-volume loss cannot presently be calculated, but about $30 \%$ of the cross-sectional area of the terminal zone of Stephenson Glacier above sea level has vanished in the past three decades. That accelerated melting of older ice-cored moraines is contributing so significantly to melt-lake expansion rather than it being the product solely of glacier recession perhaps emphasises the significance of temperature increases in causing environmental change on Heard Island. The resulting transformation of the landscape implies there have been some fundamental alterations to the nature, rates, and relative contributions of the various geomorphological processes that are shaping eastern Heard Island. Fluvial and other nonglacial processes are likely to play an increasingly significant role. Because atmospheric warming should also be accompanied by atmospheric moistening (Sun and Held 1996; Simmonds and Keay 2000), there may also be significant changes in glacial processes that could trigger further changes in glacial, glaciofluvial, and glaciolacustrine sedimentation and its interaction with coastal processes.

These changes in geomorphological processes and ongoing landscape evolution are having a pronounced impact on the character of this World Heritage Area, which is now a vastly different place to that experienced by the sealers and earliest ANARE expeditioners. In addition to impacts upon geodiversity, these changes also have implications for biodiversity, such as shoreline and other habitats, and by facilitating expansion of terrestrial vegetation. There are also implications for cultural heritage, notably archaeological sites dating from the nineteenth-century sealing days that are now subject to accelerated erosion due to changed interactions between glacial and coastal processes. Hence, this transformation has important implications for management of the Heard Island Wilderness Reserve.

Heard Island is uninhabited, infrequently visited, and about as remote from centres of direct human disturbance as any place on Earth, but there is increasing evidence of the pervasiveness of human impacts in southern polar latitudes (Liguang and Zhonqing 2001). If the climate changes responsible for glacier recession are of anthropogenic origin (Jones and others 1999; IPCC 2001), then the wilderness values and natural-process values upon which listing of this World Heritage property was partly based have in one sense been compromised. Heard Island remains about as wild and untouched as any place can be. But the changes that are occurring raise the philosophical question of whether any place on an artificially warming planet can be regarded with any validity as an untouched wilderness. These changes present the managing authority with difficult philosophical and practical issues regarding the desirability and level of any on-ground intervention for management purposes.

\section{Acknowledgements}

The authors are very grateful to Dr Grahame Budd and Dr Jon Stephenson for sharing their unpublished notes and recollections regarding ice-margin and lake positions during the 1950s-70s. Grahame Budd additionally assisted by drawing our attention to some early reference materials. We acknowledge use of climatic data made available by the Climatic Research Unit, University of East Anglia, and thank Doug Thost and Andrew Ruddell, Australian Antarctic Division, for assistance with acquisition of other climatic records. Will Powell, Paul Scott, and Lloyd Simmons provided greatly appreciated assistance in the field. The research was made possible by an Australian Antarctic Science grant.

\section{References}

Alley, R.B., and R.A. Bindschadler. 2001. The west Antarctic ice sheet and sea-level change. In: Alley, R.B., and R.A. Bindschadler. The west Antarctic ice sheet: behaviour and environment. Washington, DC: American Geophysical Union (Antarctic Research Series 77): 111.

Allison, I.F. 1980. A preliminary investigation of the physical characteristics of the Vahsel Glacier, Heard Island. Canberra: Department of Science and Technology, Antarctic Division (ANARE Scientific Reports 128).

Allison, I., and P. Keage. 1986. Recent changes in the glaciers of Heard Island. Polar Record 23 (144): 255271.

Australian Antarctic Division. 1995. Heard Island Wilderness Reserve Management Plan. Kingston, Tasmania: Antarctic Division, Department of the Environment, Sport and Territories.

Bridgewater, P.B. 1996. Protected area management in the face of climate change. Parks 6 (2): 4-13.

Budd, G.M. 1964a. The ANARE 1963 expedition to Heard 
Island. Melbourne: Antarctic Division, Department of External Affairs (ANARE Reports 74).

Budd, G.M. 1964b. Heard Island expedition, 1963. Polar Record 12 (77): 193-195.

Budd, G.M. 1970. Heard Island reconnaissance, 1969. Polar Record 15 (96): 335-336.

Budd, G.M. 1973. Glacier fluctuations at Heard Island. In: Kasser, P. (editor). Fluctuations of glaciers 1965-70. Paris: IAHS-UNESCO: 65-68, 163-164.

Budd, G.M. 2000. Changes in Heard Island glaciers, king penguins and fur seals since 1947. In: Banks, M.R., and M.J. Brown (editors). Heard Island Papers. Papers \& Proceedings of the Royal Society of Tasmania 133 (2): 47-60.

Budd, G.M., and P.J. Stephenson. 1970. Recent glacier retreat on Heard Island. In: Gow, A.J., C. Keeler, C.C. Langway, and W.F. Weeks (editors). International Symposium on Antarctic Glaciological Exploration (ISAGE), September 1968. Gentbrugge: International Association of Scientific Hydrology (IASH publication 86): 449458.

Comiso, J.C. 2000. Variability and trends in Antarctic surface temperatures from in situ and satellite infrared measurements. Journal of Climate 13 (10): 16741696.

De la Mare, W.K. 1997. Abrupt mid-twentieth-century decline in Antarctic sea-ice extent from whaling records. Nature 389: 57-60.

Doake, C.S.M., and D.G. Vaughan. 1991. Rapid disıntegration of the Wordie Ice Shelf-in response to atmospheric warming. Nature 350 (6316): 328-330.

Downes, M.C. 1996. Indexing sealers' logbooks from Heard Island. ANARE Research Notes 97.

Downes, M.C., E.H.M. Ealey, A.M. Gwynn, and P.S.Young. 1959. The birds of Heard Island. Melbourne: Antarctic Division, Department of External Affairs (ANARE Reports, Series B, 1).

Frenot, Y., J.C. Gloaguen, G. Picot, J. Bougere, and D. Benjamin. 1993. Azorella selago Hook. used to estimate glacier fluctuations and climatic history in the Kerguelen Islands over the last two centuries. Oecologia 95: 140-144.

Galloway, R., K. Kiernan, and J.A. Peterson. 1998. Effects of snow on the landscape. In: Green, K. (editor). Snow: a natural history; an uncertain future. Canberra: Australian Alps Liason Committee: 69-80.

Garvin, J.B., A. Mahmood, and C. Giguere. 1999. Taking a clear look at cloud-covered oceanic islands on a seasonal basis. EOS, Transactions American Geophysical Union 80: 49-54.

Gordon, J.E., and R.J. Timmis. 1992. Glacier fluctuations on South Georgia during the 1970s and early 1980s. Antarctic Science 4: 215-226.

Green, K. 2000. Coastal studies at Heard Island 1992/93: changes in sea surface temperature and coastal landforms. In: Banks, M.R., and M.J. Brown (editors). Heard Island Papers. Papers \& Proceedings of the Royal Society of Tasmania 133 (2): 27-32.

Hydrographic Branch. 1949. Heard Island (nautical chart). Canberra: Department of the Navy.

IPCC. 2001. Climate change 2001: synthesis report. Cam- bridge: Intergovernmental Panel on Climate Change and Cambridge University Press.

Jacka, T.H., and A. Ruddell. 1998. Construction of a temperature record for Heard Island, and comparison with glacier fluctuations. American Geophysical Union Fall Meeting, San Francisco, California, USA. Supplement to: EOS, Transactions American Geophysical Union 79 (45): F55 (Abstract U31E-04).

Jacobs, S.S., and J.C. Comiso. 1997. Climate variability in the Amundsen and Bellinghausen seas. Journal of Climate 10 (4): 697-709.

Jones, P.D., M. New, D.E. Parker, S. Martin, and I.G. Rigor. 1999. Surface air temperature and its changes over the past 150 years. Review of Geophysics 37: 173-199.

Kiernan, K., and A. McConnell. 1999. Geomorphology of the sub-Antarctic Australian territory of Heard IslandMcDonald Island. Australian Geographer 30 (20): 159195.

King, J.C. 1994. Recent climate variability in the vicinity of the Antarctic Peninsula. International Journal of Climatology 14 (4): 357-369.

Liguang S., and X. Zhonging. 2001 Changes in lead concentration in Antarctic penguin droppings during the past 3000 years. Environmental Geology 40: 12051208.

Paddick, J. 1993. A journey to SpitBay, Heard Island, 1949. Aurora 12 (3): 4-9

Paltridge, G., and S. Woodruff. 1981. Changes to global surface temperature from 1880 to 1977 derived from historical records of sea surface temperatures. Monthly Weather Review 109: 2427-2434.

Radok, U., and D. Watts. 1975. A synoptic background to glacier variations of Heard Island. In: Snow and ice symposium: proceedings of the Moscow symposium, August 1971. Wallingford: International Association of Scientific Hydrology (IASH-AISH publication 104): 4256.

Ruddell. A., and I. Allison. 1997. The sensitivity of glaciers at Heard Island to climatic changes and their recent response. In: Abstracts, 'Glaciers of the Southem Hemisphere' symposium, July 1997. Melbourne: IAMAS/ IAPSO.

Scambos, T.A., C. Hulbe, M. Fahnestock, and J.Bohlander. 2000. The link between climatic warming and break-up of ice shelves in the Antarctic Peninsula. Journal of Glaciology 46 (154): 516-530.

Simmonds, I., and K. Keay. 2000. Variability of Southern Hemisphere extratropical cyclone behaviour 19581997. Journal of Climate 13: 550-561.

Smith, V.R., and M. Steenkamp. 1990. Climatic change and its ecological implications at a subantarctic island. Oecologia 32: 239-253.

Stone, D. 1996. Impacts of climate change on selected ecosystems in Europe. Parks 6 (2): 25-37.

Sun, D.-Z., and I.M. Held. 1996. A comparison of modeled and observed relationships between interannual variations of water vapour and temperature. Journal of Climate 9: 665-675.

Vaughan, D.G., and C.S.M. Doake. 1996. Recent atmospheric warming and retreat of ice shelves on the Antarctic Peninsula. Nature 379 (6563): 328-331. 